\title{
Evaluation of resistance in a selected field strain of Haemonchus contortus to ivermectin and moxidectin using the Larval Migration on Agar Test ${ }^{1}$
}

\author{
Fernanda S. Fortes ${ }^{2 *}$, Fernando S. Kloster ${ }^{2}$, Andressa S. Schafer ${ }^{3}$, Daniele Bier ${ }^{2}$, \\ Andréia Buzatti ${ }^{2}$, Ursula Y. Yoshitani ${ }^{2}$ and Marcelo B. Molento ${ }^{2}$
}

\begin{abstract}
Fortes F.S., Kloster F.S., Schafer A.S., Bier D., Buzatti A., Yoshitani U.Y. \& Molento M.B. 2013. Evaluation of resistance in selected field strain of Haemonchus contortus to ivermectin and moxidectin using the Larval Migration on Agar Test. Pesquisa Veterinária Brasileira 33(2):183-187. Laboratório de Doenças Parasitárias, Universidade Federal do Paraná, Rua dos Funcionários 1540, Curitiba, PR 80035-050, Brazil. E-mail: fortesfs@gmail.com

Haemonchus contortus is one of the most common and economically significant causes of disease in small ruminants worldwide, and the control programs of parasitic nematodes - including $H$. contortus - rely mostly on the use of anthelmintic drugs. The consequence of the use of this, as the sole sanitary strategy to avoid parasite infections, was the reduction of the efficacy of all chemotherapeutic products with a heavy selection for resistance. The widespread of anthelmintic resistance and the difficulty of its early diagnosis has been a major concern for the sustainable parasite management on farms. The objective of this research was to determine and compare the ivermectin (IVM) and moxidectin (MOX) effect in a selected field strain of $H$. contortus with a known resistance status, using the in vitro larval migration on agar test (LMAT). Third stage larvae of the selected isolate were obtained from faecal cultures of experimentally infected sheep and incubated in eleven increasing diluted concentrations of IVM and MOX $(6,12,24,48,96,192,384,768,1536,3072$ and $6144 \mu \mathrm{g} / \mathrm{mL}$ ). The dose-response sigmoidal curves were obtained using the $R^{2}$ value of $>0.90$ and the lethal concentration $\left(\mathrm{LC}_{50}\right)$ dose for the tested anthelmintic drugs using a four-parameter logistic model. The $\mathrm{LC}_{50}$ value for MOX was significantly lower than IVM $(1.253 \mu \mathrm{g} / \mathrm{mL}$ and $91.06 \mu \mathrm{g} / \mathrm{mL})$, identifying the $H$. contortus isolate as considerably less susceptible to IVM compared to MOX. Furthermore, the LMAT showed a high consistency $(p<0.0001)$ and provided to be a useful diagnostic tool for monitoring the resistance status of IVM and MOX in H. contortus field isolate, as well as it may be used for official routine drug monitoring programs under the Ministry of Agriculture (MAPA) guidance.
\end{abstract}

INDEX TERMS: Haemonchus contortus, anthelmintics, ivermectin, moxidectin, sheep, macrocyclic lactones, in vitro, nematodes, efficacy.

RESUMO.- [Avaliação da resistência em um isolado de campo selecionado de Haemonchus contortus à ivermectina e moxidectina usando o Teste de Migração de Larvas em Ágar.] Haemonchus contortus é uma das causas

\footnotetext{
${ }^{1}$ Received on August 10, 2012.

Accepted for publication on November 23, 2012.

${ }^{2}$ Laboratório de Doenças Parasitárias, Universidade Federal do Paraná (UFPR), Rua dos Funcionários 1540, Curitiba, PR 80035-050, Brazil. *Autor para correspondência: fortesfs@gmail.com

${ }_{3}^{3}$ Programa de Pós-Graduação em Medicina Veterinária, Universidade Federal de Santa Maria (UFSM), Av. Roraima 1000, Faixa de Camobi, Km 9 , Santa Maria, RS 97105-900, Brazil.
}

mais comuns e economicamente significativas de doença em produções de pequenos ruminantes em todo o mundo, e os programas de controle de parasitas nematoides - incluindo H. contortus - baseiam-se principalmente no uso de drogas anti-helmínticas. A consequência da utilização desses compostos, como sendo a única estratégia sanitária para evitar infecções por parasitas, tem sido a redução da eficácia de todos os produtos quimioterápicos, selecionando fortemente para resistência. 0 desenvolvimento generalizado da resistência anti-helmíntica e a dificuldade de seu diagnóstico precoce têm sido uma grande preocupação para o manejo sustentável de parasitas no campo. 0 obje- 
tivo desta pesquisa foi determinar e comparar o efeito da ivermectina (IVM) e da moxidectina (MOX) em um isolado de campo selecionado de $H$. contortus com um estado de resistência conhecido, utilizando o teste in vitro de migração de larvas em ágar (LMTA). Larvas de terceiro estágio de um isolado de $H$. contortus selecionado foram obtidas a partir de culturas de fezes de ovinos infectados experimentalmente e incubadas em onze concentrações diluídas crescentes de IVM e MOX $(6,12,24,48,96,192,384,768,1536$, 3072 e $6144 \mu \mathrm{g} / \mathrm{mL}$ ). As curvas sigmoides de dose-resposta foram obtidas utilizando o valor de $R^{2}>0,90$ e a dose de concentração letal $\left(\mathrm{CL}_{50}\right)$ para as drogas anti-helmínticas testadas, utilizando um modelo logístico de quatro parâmetros. $\mathrm{O}$ valor de $\mathrm{CL}_{50}$ para MOX foi significativamente menor do que para IVM $(1,253 \mu \mathrm{g} / \mathrm{mL}$ e $91,06 \mu \mathrm{g} / \mathrm{mL})$, identificand o o isolado de $H$. contortus como consideravelmente menos suscetível à IVM em comparação à MOX. Além disso, o LMTA mostrou uma alta consistência $(p<0,0001)$ e pode ser uma ferramenta útil de diagnóstico para monitorar o status de resistência de IVM e MOX em isolado de campo de H. contortus, assim como ser utilizado de forma oficial e em rotina para programas de monitoramento das drogas sob a demanda do Ministério da Agricultura (MAPA).

TERMOS DE INDEXAÇÃO: Haemonchus contortus, anti-helmínticos, ivermectina, moxidectina, ovinos, lactonas macrocíclicas, in vitro, nematoides, eficácia.

\section{INTRODUCTION}

Haemonchus contortus is one of the most important gastrointestinal nematodes of small ruminant production worldwide due to its high prevalence and pathogenicity, causing serious economic losses (Kaplan 2004) and anthelmintic drugs are commonly used as the sole method to control this parasite. Nonetheless, the intensive use of all the available compounds has led to the widespread development of anthelmintic resistance in all major sheep producing countries (Van Wyk et al. 1999, Papadopoulos 2008, Molento et al. 2011, Kaplan \& Vidyashankar 2012, Veríssimo et al. 2012).

Among the most widely used drugs, the macrocyclic lactones (MLs) such as ivermectin (IVM), an avermectin class compound, and moxidectin (MOX), a milbemycin, have a broad spectrum of activity against parasitic nematodes in livestock and humans. Resistance to these compounds has been detected in different nematodes in Brazil, also H. contortus (Echevarria et al. 1996, Thomaz-Soccol et al. 2004, Rosalinski-Moraes et al. 2007, Almeida et al. 2010, Cruz et al. 2010, Sczesny-Moraes et al. 2010, Veríssimo et al. 2012).

There is an urgent need to determine the drug efficacy status to continue to support farm planning and the sustainable use of the remaining effective anthelmintics, reducing the spread of resistant parasites (Coles et al. 2006, Demeler et al. 2010). The gold standard method for detecting anthelmintic resistance is the controlled efficacy test based on the reduction in worm counts after the sacrifice of animals. Although the most reliable test available to date to detect drug resistance, the test is extremely expensive, laborious and time consuming. The faecal egg count reduction test (FECRT), which compares the egg counts performed pre- and post-treatment can define the percentage of efficacy by reducing egg numbers. Although the method is employed on all anthelmintic classes and has been commonly used to monitor resistance in nematodes, it does not measure the reduction of adult parasite number (Coles et al. 2006, De Graef et al. 2012, Kaplan \& Vidyashankar 2012).

Therefore, a rapid and more cost effective diagnosis method for anthelmintic resistance is needed. Various in vitro methods have been developed in the last 30 years (Gill et al. 1995, d'Assonville et al. 1996, Molento \& Prichard 2001, Taylor et al. 2002, Coles et al. 2006, Demeler et al. 2010), having the main characteristic of avoiding the "animal - in vivo" effect (i.e. breed, age, body fat/score), which can significantly alter the drug pharmacokinetics, as a consequence of different rates of absorption, metabolism and the time to reach the target tissues.

Among the in vitro methods, the migration tests consist in a simple, rapid and cost effective alternative for the analysis of the effects of a few classes of anthelmintics. The main mechanism to be tested is the muscle paralysis caused to the nematodes, which can be viewed as a reduction of migration when comparing the control and treated groups. The Larval Migration on Agar Test (LMIT) is being used as a diagnostic tool to detect and monitor the resistance to MLs in the Laboratory (d'Assonville et al. 1996, Molento \& Prichard 2001, Demeler et al. 2010). Therefore, the objective of the present study was to evaluate and compare the IVM and MOX effect in a $H$. contortus, isolated from a sheep farm with a history of IVM resistance and MOX susceptibility (Veríssimo et al. 2012), using a modified migration test (Molento \& Prichard 2001).

\section{MATERIALS AND METHODS}

Parasite field isolate and production of faecal culture from the isolate. The parasite field isolate used in this study was obtained from a sheep farm located in São Paulo State, Brazil, with reports of resistance to IVM (16\%) and susceptibility to MOX (99\%) by the FECRT conducted previously (Veríssimo et al. 2012). The original parasite population was composed by Haemonchus sp. (59\%), Cooperia sp. (22\%), Trichostrongylus sp. (11\%) and Teladorsagia sp. (8\%). Faecal samples containing nematode eggs were collected from sheep and were submitted to faecal cultures for 7 days to obtain third stage larvae $\left(\mathrm{L}_{3}\right)$. The infective $\mathrm{L}_{3}$ obtained were stored in distilled water under refrigeration until used to artificially infect new parasite-free sheep in order to obtain pure cultures of $H$. contortus (see detail Protocol below).

Experimental infections and the production of faecal cultures 1 and 2 (isolate SP15030vi2011). Four lambs were selected and treated orally with oxfendazole $2.5 \mathrm{mg} / \mathrm{kg}$ body weight (BW) (Oxfaden ${ }^{\circledR}$, Biovet) and levamisole at $5.0 \mathrm{mg} / \mathrm{kg} / \mathrm{BW}$ (Riper$\mathrm{Col}^{\circledR} \mathrm{L}$, Fort Dodge) for three consecutive days, to remove every natural parasite infection. Faecal samples were collected for 4 weeks from the animals to confirm their parasite-free status. After that the animals were kept on worm-free paddocks until the experimental infections.

Two lambs (Group 1) were artificially infected with $8000 \mathrm{~L}_{3}$ of gastrointestinal nematodes by oral gavage. The infection was allowed to establish for at least 28 days. From day 28 to 34 faecal samples were taken for EPG and larvae culture. The animals were euthanized on day 34 post-infection and the $H$. contortus adults were directly collected from the abomasum. The adult worms 
were immediately placed into Petri dishes containing saline solution at $36^{\circ} \mathrm{C}$ and kept in an incubator for a period of 2-12 hours for completion of the female oviposition. The eggs were harvested and placed in a sedimentation glass. Then, the eggs were mixed with autoclaved horse feces to obtain a monospecific faecal culture (Faecal culture 1).

Two lambs (Group 2) were artificially infected by the oral administration of $8000 \mathrm{~L}_{3}$ of $H$. contortus obtained from the faecal culture 1 . After the confirmation of the establishment of the infection, new faecal cultures were prepared to produce a pure $H$. contortus larval culture (Faecal culture 2). The infective larvae from the faecal culture 2 were identified and stored in distilled water up to 30 days until it was used with the in vitro assays. Although not included in the Parasite Isolate Database, the nomenclature code used for the present isolate (SP15030vi2011) was based on that of CARS (Consortium for Anthelmintic Resistance and Susceptibility) using the following code: state of origin/code number of the farm sampled/host animal/year of isolation.

In vitro Larval Migration on Agar Test (LMAT). The LMAT was performed following the technique modified by Molento \& Prichard (2001). The $\mathrm{L}_{3}$ collected from the faecal culture 2 were exsheathed using $0.3 \%$ sodium hypochlorite and when more than $90 \%$ of the motile larvae were exsheathed, they were washed three times in distilled water and subdivided in groups of $400 \mathrm{~L}_{3}$ per well in triplicates. Each group of larvae was mixed with distilled water to make a total volume of $0.5 \mathrm{~mL}$ while drug dilutions were prepared in separate tubes (total volume of $0.5 \mathrm{~mL}$ ). Eleven drug concentrations were tested $(6,12,24,48,96,192,384,768$, 1536,3072 and $6144 \mu \mathrm{g} / \mathrm{mL}$ ) for $1 \%$ ivermectin (Ivomec ${ }^{\circledR}$, Merial Saúde Animal) and 1\% moxidectin (Cydectin ${ }^{\circledR}$, Fort Dodge). The $\mathrm{L}_{3}$ plus the drug dilutions were placed at $27^{\circ} \mathrm{C}$ for $6 \mathrm{~h}$ (first incubation). After that, an $1.4 \%$ agar solution was added to the treated larvae plus drug solution and immediately transferred to a previously prepared apparatus made of a Petri dish containing a plastic mesh in the middle of the base, a metal mesh and a plastic cylinder on the top. The apparatus was previously filled with $22 \mathrm{~mL}$ of distilled water and stored at $-20^{\circ} \mathrm{C}$ allowing the frozen water to cover the mesh. After the addition of the whole content, the apparatus was placed in an incubator for $18 \mathrm{~h}$ at $27^{\circ} \mathrm{C}$ under a $150 \mathrm{MHz}$ light bulb, to stimulate the larval migration - out the agar portion. After the second migration, the liquid portion containing the migrated larvae was transferred into a $50 \mathrm{~mL}$ tube and centrifuged at $3000 \mathrm{rpm}$ for 5 minutes where the supernatant was removed. The tubes were then vortex and triplicate samples of 1 $\mathrm{mL}$ were taken. The final counts were made by the average of the aliquots multiplied by 10 .

All experimental procedures reported in this manuscript were examined and approved by the Animal Use Ethics Committee of the Agricultural Sciences Campus of the Federal University of Paraná, Brazil (Protocol 021/2010).

Statistical analysis. The $50 \%$ lethal concentration $\left(\mathrm{LC}_{50}\right)$ and the standard error were measured by a non-linear regression model which resulted in a sigmoidal concentration response curve (four-parameter logistic equation with a variable slope), using the program GraphPad Prism ${ }^{\circledR}$ 5.01. All analyses were carried out after transforming the data into their logarithm $(X=\log X)$, before calculating the $\log \mathrm{LC}_{50}$ values ( $\mathrm{LC}_{50}$ values), 95\% confidence intervals and $R^{2}$ values. In addition, the $p$-values for the $\mathrm{LC}_{50}$ values of IVM and MOX responses were calculated using the same program.

\section{RESULTS}

The nematode genera recovered from the faecal culture 2 showed $>96 \%$ of Haemonchus contortus genus followed by $<3 \%$ of Cooperia sp. and Trichostrongylus sp.. All in vi- tro tests were run with the $H$. contortus $\mathrm{L}_{3}$ from the faecal culture 2. For the inclusion of experimental data, it was necessary to attend two criteria: a migration ratio of at least $80 \%$ in the negative control and $R^{2}$ values $>0.90$. The dose-response curves for IVM and MOX drugs using the in vitro LMAT are presented in Figure 1.

The statistical analysis of the curves was performed using the $\mathrm{LC}_{50}$ values. The results correctly identified the $H$. contortus isolate resistant to IVM and susceptible to MOX, showing the IVM-LC ${ }_{50}$ value of $91.06 \mu \mathrm{g} / \mathrm{mL}$ and the MOX$-\mathrm{LC}_{50}$ value of $1.253 \mu \mathrm{g} / \mathrm{mL}$ (Table 1 ). The results were statistically significant $(p<0.0001)$ for both drugs.

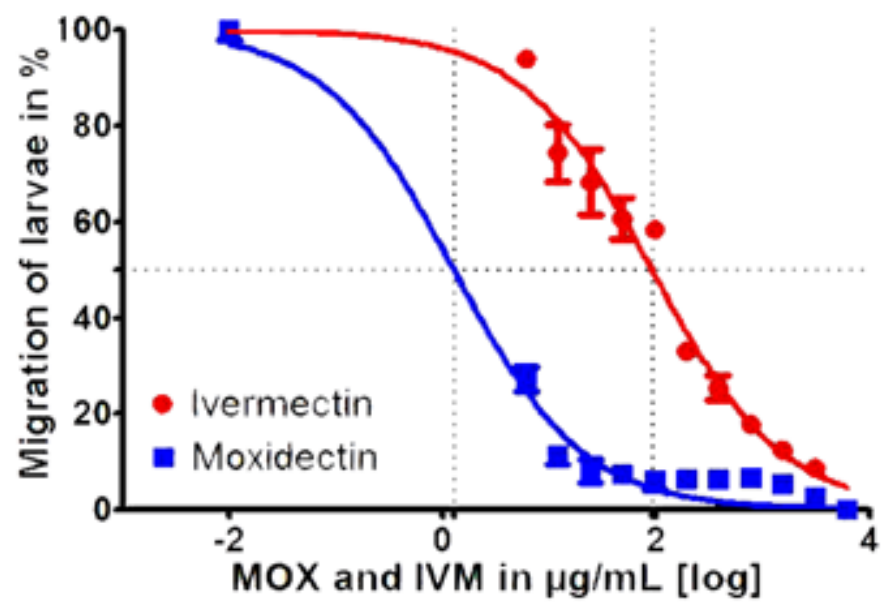

Fig.1. Dose-response curves obtained with the Larval Migration on Agar Test with the SP15030vi2011 isolate of Haemonchus contortus using ivermectin (IVM, solid line) and moxidectin (MOX, dashed line). Error bars indicate the standard error. The error bars are not seen where the differences between the values observed for all concentrations tested was 0 or very close to 0 .

Table 1 . The $\mathrm{LC}_{50}$ values, with the $95 \%$ confidence interval $(95 \% \mathrm{CI}), \log \mathrm{LC}_{50}$ values, $\boldsymbol{R}^{2}$ and $\boldsymbol{p}$-values using ivermectin (IVM) and moxidectin (MOX) in the Larval Migration on Agar Test with the isolate SP15030vi2011 of Haemonchus contortus

\begin{tabular}{lcc}
\hline & MOX & IVM \\
\hline $\mathrm{LC}_{50}$ & $1.253 \mu \mathrm{g} / \mathrm{mL}$ & $91.06 \mu \mathrm{g} / \mathrm{mL}$ \\
$95 \% \mathrm{CI}$ & $0.704-2.229 \mu \mathrm{g} / \mathrm{mL}$ & $75.53-109.8 \mu \mathrm{g} / \mathrm{mL}$ \\
$\mathrm{Log} \mathrm{LC}_{50}$ & 0.099 & 1.959 \\
$R^{2}$ & 0.97 & 0.96 \\
$p$-value & $<0.0001$ &
\end{tabular}

\section{DISCUSSION}

It is very important to monitor anthelmintic efficacy at regular intervals to detect subtle changes, as early as possible in order to avoid the establishment of anthelmintic resistance. This may be performed by accessible and sensitive in vitro diagnostic tests, determining even which drugs are still effective against a particular parasite population to enable the choice of an anthelmintic for therapeutic use in the field (Kaplan 2004, Demeler et al. 2010, Molento et al. 2011). The larval development tests (LDT) are the most commonly employed and was able to easily discriminate between susceptible and resistant parasite isolates. 
The LDT showed ability to identify low levels of resistant worms in a population, but the execution of these exams present some difficulties (Dolinská et al. 2012). Another potential alternative that is still being studied for the detection of resistant parasites is the larval migration tests (LMT). The LMT has being used for the detection of drug resistance for IVM, MOX and the benzimidazoles in sheep, goats and cattle nematodes (Wagland et al. 1992, Rabel et al. 1994, Molento \& Prichard 2001, Gatongi et al. 2003, Kaplan et al. 2007, Demeler et al. 2010, Borges et al. 2011, Almeida et al. 2012).

The development of IVM resistance and also the concomitant loss of sensitivity to MOX is an ongoing debate (Conder et al. 1993, Shoop et al. 1993, Molento et al. 1999, Ranjan et al. 2002, De Graef et al. 2012). El-Abdellati et al. (2010) suggest that when detecting resistance to IVM the use of any type of ML's is inappropriate. However, the rate of resistance differs between compounds and occurs slower to MOX than to IVM (Ranjan et al. 2002, Le Jambre et al. 2005). While the resistance to one anthelmintic can be detected, another drug of the same class may still remain highly effective (Kaplan \& Vidyashankar 2012). Although increasing reports of resistance to MOX in nematodes throughout the world, severe multidrug resistance was detected, with MOX remaining as the drug with better effect (Mortensen et al. 2003, Kaplan et al. 2007). So, our results indicate that MOX could have some potential application in controlling $\mathrm{H}$. contortus in sheep on that farm and this might be true to other gastrointestinal nematodes.

The disturbing anthelmintic resistance status previously detected by FECRT was confirmed by the in vitro test in the present trial, as shown by the different LD50's. This is in accordance with other reports, where sheep nematode populations showed high resistance against MLs in vivo and also were less susceptible in vitro, using larval development tests (Hubert \& Kerboeuf 1992, Taylor et al. 2002). The problem of anthelmintic resistance, identified in both tests, is possibly the situation that predominates in most of the sheep farms in Brazil. Therefore, we suggest that the Ministry of Agriculture, MAPA could officially adopt in vitro tests to be used by drug-monitoring programs. Before that, it is essential to improve and adapt standard operating protocols for running and interpreting the LMAT in order to make this test applicable for routine practice. It is necessary to test different isolates with different status of drug resistance in different laboratories, using the identical protocol, to confirm the reproducibility and repeatability of the LMAT data.

In conclusion, the in vitro LMAT described here was successfully used to generate reliable $(p<0.0001)$ dose-response curves for the tested drugs. The obtained $\mathrm{LC}_{50}$ value for MOX was 72.67 times lower than for the IVM, identifying this $H$. contortus isolate highly resistant to IVM. The present data also shows the potential of using the LMAT for the analysis of resistance to MLs and can provide a useful diagnostic tool for monitoring anthelmintic resistance.

Acknowledgements.- We are very grateful to Conselho Nacional de Desenvolvimento Científico e Tecnológico (CNPq) for the financial support
(Processo no. 559614/2009-8) and to Coordenação de Aperfeiçoamento de Pessoal de Nível Superior (CAPES/REUNI) for providing a doctoral degree scholarship to Fernanda S. Fortes.

\section{REFERENCES}

Almeida G.D., Feliz D.C., Heckler R.P., Borges D.G., Onizuka M.K., Tavares L.E., Paiva F. \& Borges F.A. 2012. Ivermectin and moxidectin resistance characterization by larval migration inhibition test in field isolates of Cooperia spp. in beef cattle, Mato Grosso do Sul, Brazil. Vet. Parasitol. (Epub ahead of print)

Almeida F.A., Garcia K.C.O.D., Torgerson P.R. \& Amarante A.F.T. 2010. Multiple resistance to anthelmintics by Haemonchus contortus and Trichostrongylus colubriformis in sheep in Brazil. Parasitol. Int. 59:622-625.

Borges F.A., Rossini J.B., Velludo P.P., Buzzulini C., Costa G.H., Molento M.B. \& Costa A.J. 2011. Weak phenotypic reversion of ivermectin resistance in a field resistant isolate of Haemonchus contortus by verapamil. Pesq. Vet. Bras. 31:731-736.

Coles G.C., Jackson F., Pomroy W.E., Prichard R.K., von Samson-Himmelstjerna G., Silvestre A., Taylor M.A. \& Vercruysse J. 2006. The detection of anthelmintic resistance in nematodes of veterinary importance. Vet. Parasitol. 136:167-85.

Conder G.A., Thompson D.P. \& Johnson S.S. 1993. Demonstration of co-resistance of Haemonchus contortus to ivermectin and moxidectin. Vet. Rec. 132:651-652.

Cruz D.G., Rocha L.O., Arruda S.S., Palieraqui J.G.B., Cordeiro R.C., Santos Junior E., Molento M.B. \& Santos C.P. 2010. Anthelmintic efficacy and management practices in sheep farms from the state of Rio de Janeiro, Brazil. Vet. Parasitol. 170:340-343.

d'Assonville J.A., Janovsky E. \& Verster A. 1996. In vitro screening of $\mathrm{Ha}$ emonchus contortus third stage larvae for ivermectin resistance. Vet. Parasitol. 61:73-80.

De Graef J., Sarre C., Mills B.J., Mahabir S., Casaert S., De Wilde N., Van Weyenberg M., Geldhof P., Marchiondo A., Vercruysse J., Meeus P. \& Claerebout E. 2012. Assessing resistance against macrocyclic lactones in gastro-intestinal nematodes in cattle using the faecal egg count reduction test and the controlled efficacy test. Vet. Parasitol. <http://dx.doi. org/10.1016/j.vetpar.2012.04.040>

Demeler J., Küttler U., El-Abdellati A., Stafford K., Rydzik A., Varady M., Kenyon F., Coles G., Höglund J., Jackson F., Vercruysse J. \& von Samson-Himmelstjerna G. 2010. Standardization of the larval migration inhibition test for the detection of resistance to ivermectin in gastro intestinal nematodes of ruminants. Vet. Parasitol. 174:58-64.

Dolinská M., Königová A. \& Várady M. 2012. Is the micro-agar larval development test reliable enough to detect ivermectin resistance? Parasitol. Res. 111:2201-2204.

Echevarria F., Borba M.F.S., Pinheiro A.C., Waller P.J. \& Hansen J.W. 1996. The prevalence of anthelmintic resistance in nematode parasites of sheep in Southern Latin America. Brazil. Vet. Parasitol. 62:199-206.

El-Abdellati A., Geldhof P., Claerebout E., Vercruysse J. \& Charlier J. 2010. Monitoring macrocyclic lactone resistance in Cooperia oncophora on a Belgian cattle farm during four consecutive years. Vet. Parasitol. 171:167-171.

Gatongi P.M., Njoroge J.M., Scott M.E., Ranjan S., Gathuma J.M., Munyua W.K., Cheruiyot H. \& Prichard R. 2003. Susceptibility to IVM in a field strain of Haemonchus contortus subjected to four treatments in a closed sheep-goat flock in Kenya. Vet. Parasitol. 110:235-240.

Gill J.H., Redwin J.M., Van Wyk J.A. \& Lacey E. 1995. Avermectin inhibition of larval development in Haemonchus contortus: Effects of ivermectin resistance. Int. J. Parasitol. 25:463-470.

Hubert J. \& Kerboeuf D. 1992. A microlarval development assay for the detection of anthelmintic resistance in sheep nematodes. Vet. Rec. 130:442-446.

Kaplan R.M. 2004 Drug resistance in nematodes of veterinary importance: A status report. Trends in Parasitology 20:477-481.

Kaplan R.M. \& Vidyashankar A.N. 2012. An inconvenient truth: Global worming and anthelmintic resistance. Vet. Parasitol. 186:70-78. 
Kaplan R.M., Vidyashankar A.N., Howell S.B., Neiss J.M., Williamson L.H. \& Terrill T.H. 2007. A novel approach for combining the use of in vitro and in vivo data to measure and detect emerging moxidectin resistance in gastrointestinal nematodes of goats. Int. J. Parasitol. 37:795-804.

Le Jambre L.F., Geoghegan J. \& Lyndal-Murphy M. 2005. Characterization of moxidectin resistant Trichostrongylus colubriformis and Haemonchus contortus. Vet. Parasitol. 128:83-90.

Molento M.B., Fortes F.S., Pondelek D.A.S., Borges F.A., Chagas A.C.S., Torres-Acosta J.F.J. \& Geldhof P. 2011. Challenges of nematode control in ruminants: Focus on Latin America. Vet. Parasitol. 180:126-132.

Molento M.B. \& Prichard R.K. 2001. Effect of multidrug resistance modulators on the activity of ivermectin and moxidectin against selected strains of Haemonchus contortus infective larvae. Pesq. Vet. Bras. 21:117-121.

Molento M.B., Wang G.T. \& Prichard R.K. 1999. Decreased ivermectin and moxidectin sensitivity in Haemonchus contortus selected with moxidectin over 14 generations. Vet Parasitol. 86:77-81.

Mortensen L.L., Williamson L.H., Terrill T.H., Kircher R., Larsen M. \& Kaplan R.M. 2003. Evaluation of prevalence and clinical implications of anthelmintic resistance in gastrointestinal nematodes of goats. J. Am. Vet. Med. Assoc. 23:495-500.

Papadopoulos E. 2008. Anthelmintic resistance in sheep nematodes. Small Rum. Res. 76:99-103.

Rabel B., McGregor R. \& Douch P.G. 1994. Improved bioassay for estimation of inhibitory effects of ovine gastrointestinal mucus and anthelmintics on nematode larval migration. Int. J. Parasitol. 24:671-676.

Ranjan S., Wang G.T., Hirschlein C. \& Simkins K.L. 2002. Selection for resistance to macrocyclic lactones by Haemonchus contortus in sheep. Vet. Parasitol. 103:109-117.
Rosalinski-Moraes F., Moretto L.H., Bresolin W.S., Gabrielli I., Kafer L., Zanchet I.K., Sonaglio F. \& Thomaz-Soccol V. 2007. Resistencia anti-helmintica em rebanhos ovinos da regiao da associação dos municipios do alto Irani (AMAI), oeste de Santa Catarina. Cienc. Anim. Bras. 8:559-565.

Sczesny-Moraes E.A., Bianchin I., da Silva K.F., Catto J.B., Honer M.R. \& Paiva F. 2010. Anthelmintic resistance of gastrointestinal nematodes in sheep, Mato Grosso do Sul, Brazil. Pesq. Vet. Bras. 30:229-236.

Shoop W.L., Haines H.W., Michael B.F. \& Eary C.H. 1993. Mutual resistance to avermectins and milbemycins: oral activity of ivermectin and moxidectin against ivermectin-resistant and susceptible nematodes. Vet. Rec. 133:445-447.

Taylor M.A., Hunt K.R. \& Goodyear K.L. 2002. Anthelmintic resistance detection methods. Vet. Parasitol. 103:183-194.

Thomaz-Soccol V., Souza F.P., Sotomaior C., Castro E.A., Milczewski V., Mocelin G. \& Pessoa e Silva M.C. 2004. Resistance of gastrointestinal nematodes to anthelmintics in sheep (Ovis aries). Braz. Arch. Biol. Technol. 47:41-47.

Van Wyk J.A., Stenson M.O., Vander Merwe J.S., Vorster R.J. \& Viljoen P.G. 1999. Anthelmintic resistance in South Africa: surveys indicate an extremely serious situation in sheep and goat farming. Onderstepoort J. Vet. Res. 66:273-284.

Veríssimo C.J., Niciura S.C.M., Alberti A.L.L., Rodrigues C.F.C., Barbosa C.M.P., Chiebao D.P., Cardoso D., da Silva G.S., Pereira J.R., Margatho L.F.F., da Costa R.L.D., Nardon R.F., Ueno T.E.H., Curci V.C.L.M. \& Molento M.B. 2012. Multidrug and multispecies resistance in sheep flocks from São Paulo state, Brazil. Vet. Parasitol. 187:209-216.

Wagland B.M., Jones W.O., Hribar L., Bendixsen T. \& Emery D.L. 1992. A new simplified assay for larval migration inhibition. Int. J. Parasitol. 22:1183-1185. 